\title{
Consumer perception of Brazilian traced beef
}

\author{
Júlio Otávio Jardim Barcellos ${ }^{1,2,3}$, Alexandre de Melo Abicht ${ }^{1,2}$, Fernanda Scharnberg \\ Brandão ${ }^{1,2}$, Maria Eugênia Andrighetto Canozzi ${ }^{2}$, Fernando Carbonari Collares ${ }^{2}$
}

\footnotetext{
1 Programa de Pós-Graduação em Agronegócios - CEPAN - UFRGS.

${ }^{2}$ Núcleo de Estudos em Sistemas de Produção de Bovinos de Corte e Cadeia Produtiva (NESPRO) - UFRGS

${ }^{3}$ Pesquisador de Produtividade CNPq e Beneficiário de Auxílio Financeiro no. 2842/2010 da CAPES/BRASIL.
}

\begin{abstract}
The objective of this study was to determine consumers understanding of beef traceability, identifying how consumers value this meat and traceability elements to be presented on retail shelves. The method used in this study was a survey through the internet applying the Sphinx software. The sample consisted of 417 consumers, mostly living in Porto Alegre, Brazil. Consumers are aware of certified beef, consider it important, but this is not a demand. As to traced beef, most consumers (62.4\%) are in favor of mandatory traceability of beef cattle in Brazil, but $86.6 \%$ disagree with the destination of traced beef only to the foreign market. The majority of people are willing to pay more for traced beef and consider traceability a market opportunity, used as a differentiating tool.
\end{abstract}

Key Words: agribusiness, certification, differentiation, quality, traceability

\section{Introduction}

The problems experienced by livestock producers have increased with the public concerns with the safety of beef and dairy cattle products, demanding efforts from governments and the industry to recover the confidence of consumers (Sepúlveda et al., 2008) and changing the their profile at the time of purchase (Bernués et al., 2003a). According to Jones et al. (2004), the profile of the consumers started to change in 1986, when BSE (Bovine Spongiform Encephalopathy) was first diagnosed in cattle and when a person died due to Variant Cruetzfeldt-Jacob Disease (vCJD), which is a BSE variant affecting human beings, in the beginning of 1996 in The UK. According to Caswell (2006), food purchase is determined by intrinsic attributes, such as food safety, nutrition, tenderness, texture, functionality, convenience, production system, and by extrinsic attributes, including brand and price.

A recent approach to ensure food safety to consumers is the certification process, in which an official and legally acknowledged company provides a certificate or equivalent assurance that the food product or production system complies with food safety requirements (CODEX ALIMENTARIUS, 2007).

Food traceability in Brazil is based on this certification concept. Beef was one of the first foods to be included in this process by means of SISBOV (Serviço Brasileiro de Rastreabilidade da Cadeia Produtiva de Bovinos e Bubalinos
-Brazilian Traceability System of the Beef Production Chain), effective since 2002 and initially established to comply with the requirements of the European Union for beef imports. According to Rijswijk et al. (2008), certification provides differentiation, as it allows tracing and tracking a food product and its ingredients throughout the production chain.

However, part of the Brazilian traced beef produced for exports is sold in the domestic market, and therefore, to promote its consumption, it is essential to determine the consumers perceptions of this product and their willingness to pay more to obtain beef quality and safety assurance.

This study aimed at investigating the perception Brazilian consumers have of certified beef, and especially, of traced beef.

\section{Material and Methods}

A survey was carried out and, based, on a review of articles published in Brazilian and international journals, a semi-structured questionnaire was elaborated. The questionnaire consisted of multiple-choice questions (single and multiple answers or scored according to a 5-score Likerttype scale) and subjective questions (answers type "Else? Explain.”). The questionnaire was subdivided in seven sections: consumer profile, consumption habits, knowledge of certification and differentiation, beef purchase process, knowledge of beef traceability, beef consumption, and a general question. 
The questionnaire was presented to a sample of 417 consumers from different Brazilian cities, with a predominance of consumers living in Porto Alegre (39.3\%). The sample was classified as convenience non-probabilistic. The return rate of the survey questionnaire was $10 \%$.

The questionnaire was built using the software Sphinx 5.0, and was presented to the respondents on the Internet. Data were collected between August 11 and September 22, 2008, totaling 42 collection days. Answers were analyzed by the above-mentioned program.

\section{Results and Discussion}

Relative to the profile of the respondents, the main attributes taken into account when choosing beef were tenderness, color, and fat content. Price was the fourth purchase factor. This may be explained by the high income and education level of the respondents. In a survey carried out with beef consumers in three large Spanish cities (Madrid, Zaragoza and León), Sepúlveda et al. (2008) also found that price was not a priority when making the purchase decision, whereas the most valued attributes were region and origin of production. In Chile, quality was the main factor determining purchase decision-making of beef consumers (Villalobos et al., 2010).

At the time of purchase, $79.1 \%$ of the respondents answered that health was the main aspect related to beef quality. Only $20.6 \%$ of the respondents considered traceability when making the purchase decision, and organic certification was the last factor. This demonstrates that the surveyed consumers had insufficient knowledge on traceability, as its concept is directly associated to health issues (Figure 1).

Approximately half (53.5\%) of the respondents demonstrated some knowledge of beef differentiation and

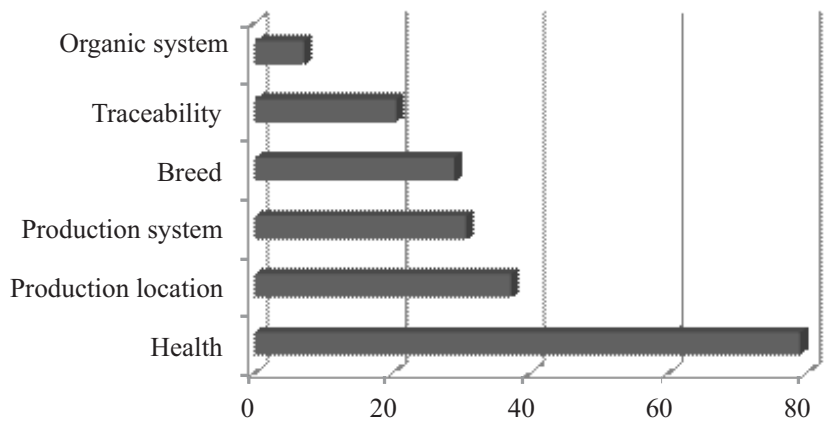

Figure 1 - Factors considered most important at the time of purchase (the \% values of the parameters were calculated in relation to the total sample value - $\mathrm{N}=417$ ). certification mechanisms. This is essential to establish beef differentiation mechanisms, as consumers are becoming increasingly demanding, have access to more information, and believe quality is not a mere marketing tool, but a philosophy (Barcellos et al., 2004). This is explained by the fact that new definitions are constantly added to the concept of quality. According to Gómez (2004), quality is defined by value attributes, which are becoming increasingly distant from basic nutritional quality or safety of a food product and which define products relative to their organoleptic characteristics and eating satisfaction as influenced by social-cultural, environmental, ethical, and traditional factors.

Differentiation is an opportunity to expand the beef market, as there are specific consumer niches that are still not supplied by local production (Malafaia et al., 2006). Machado (2005) also mentions that exclusive retail channels that sell fresh products in a differentiated manner, such as beef, are still lacking.

Most respondents (85.6\%) answered they knew about beef certification, but only $53 \%$ associated it to product differentiation. Only $25 \%$ of the surveyed consumers said they required certification when purchasing beef, which is opposite to the observed trend of an increasing number of certification labels in food products, which are considered as important by consumers, to check the quality of these products (Coltro, 2007).

Considering the respondents that required certification, the analysis showed that health inspection was preferred by most (61.9\%), indicating that the main concern at the time of purchase is food safety. On the other hand, factors associated to specific differentiations as a whole account for $38 \%$ of purchase decisions.

As to seeing the beef certification label at the time of purchase, only $39.8 \%$ of the respondents said they did not identify the certificate. The analysis of content showed that the main certificate types identified are stamps, tags, stickers and/or labels on the beef package.

In the total sample, $70.5 \%$ are aware of health certifications (SIF, CISPOA, SIM) and $47 \%$ are aware of beef traceability certification (Table 1 ). Although traceability is

Table 1 - Certification types known by the respondents

\begin{tabular}{lcc}
\hline Certification & $\mathrm{N}$ & $\% *$ \\
\hline Health (SIF/CISPOA/SIM) & 294 & 70.5 \\
Traceability & 196 & 47.0 \\
Brand & 190 & 45.6 \\
Beef quality certification & 152 & 36.5 \\
Organic beef certification & 99 & 23.7 \\
\hline
\end{tabular}

* \% values of the parameters were calculated in relation to the total sample value $(\mathrm{N}=417)$. 
the second factor of consumer awareness, it is associated with health, because it records all events of the production process and also allows tracing the product origin.

Interestingly, traceability was seldom taken into consideration (3.4\%) as a beef certification criterion by the respondents (Table 2).

During the purchase process, $38.4 \%$ of the respondents said they identified the origin of the purchased beef by cattle breed, place of production, geographic conditions, and indication of origin. Therefore, as consumers do not demand beef to be certified, they also do not try to identify the origin of the process during the purchase. Tootelian \& Segale (2004) found that most consumers do not consider the place of origin of the purchased beef because they have confidence in the choice of the products they purchase, and therefore, it is not necessary to check the origin. On the other hand, the survey carried out by Bernués et al. (2003b) in five European countries (England, France, Scotland, Italy, and Spain) between October 1999 and January 2000 verified that beef origin is the second most valued attribute of consumers in those countries ( $86.7 \%$ of the respondents).

A rate of $54.7 \%$ of surveyed consumers was aware of the Brazilian beef traceability system (SISBOV), which demonstrates that the sample consisted of informed consumers. However, a significant part of the consumers is still not aware of the SISBOV, which may be explained by the lack of institutional mechanisms to inform the public about traceability.

Another aspect analyzed was the consumer perception of beef traceability, with $50.4 \%$ of the respondents considering it an opportunity to promote business in the production chain, and $41 \%$ saying that the system existed only due to EU requirements to import Brazilian beef.

Therefore, it may be inferred that traceability is considered a strategic mechanism to have access to foreign markets due to the assurance and reliability of product and process information provided to consumers and the first goal when seeking competitiveness (Vieira et al., 2007). Furthermore, $85 \%$ of the respondents answered that beef traceability is a differentiation tool, as shown by other

Table 2 - Certifications required by the consumers at the purchase

\begin{tabular}{lcc}
\hline Certification & N & $\% *$ \\
\hline Health inspection & 47 & 54.0 \\
Origin & 15 & 17.2 \\
Stamp/tag/label indicating quality & 10 & 11.5 \\
Breeder/retailer/packing plant brand & 9 & 10.3 \\
Traceability & 3 & 3.4 \\
Organic system & 2 & 2.3 \\
Legal packing plant & 1 & 1.1 \\
*\% values of the parameters were calculated in relation to the total sample value \\
(N = 417).
\end{tabular}

authors (Ferreira et al., 2007), who considered it an important mechanism to add value to the product, as it is valued by consumers.

Most respondents (62.4\%) said they were in favor of mandatory beef traceability in Brazil, suggesting the trend that consumers will increasingly demand that beef be traced, and $86.6 \%$ disagreed with the exclusive destination of traced beef to the foreign market, because they want this type of beef to be available in the domestic market.

It must be mentioned that the traced beef cuts exported to the European Union are those with the highest values, such as rump cap, chuck tender, rump, fillet and strip loin. However, these cuts comprise only $30 \%$ of the carcass, and the remaining cuts are sold as a commodities in the Brazilian market, suggesting a possible niche market for traced beef in Brazil. According to Neves \& Scare (2006), the Brazilian domestic market needs to absorb the beef cuts that cannot be exported, and these must have added value when sold. Currently, when the cuts for export do not comply with the required specifications (weight, size, fat content) of the European customers, they are sold in the domestic market, where the advantages of their certification process (traceability) are not demonstrated or valued, as well as the remaining $70 \%$ of the carcass.

Out of the respondents, 53\% answered they would be willing to pay a higher price for traced beef, whereas $13.7 \%$ did not answer this question. In a survey carried out by Brisola et al. (2005) with consumers in Brasília, 71.8\% agreed to pay more for traced meat in relation to traditional cuts. On the other hand, Angulo \& Gil (2007) found that only $27 \%$ of the Spanish consumers surveyed were willing to pay more for beef products that indicated concern with the maintenance of food safety (traceability), and these would pay $5 \%$ more over the product price in the retail shelf. A similar study carried out by Velho et al. (2009) showed that consumers demand foods presenting good quality and reliable certifications demonstrating and ensuring food quality, but are willing to pay only 5 to $10 \%$ for certification more than the current market value, probably because their monthly income does not allow them to pay more for this attribute.

\section{Conclusions}

Most Brazilian consumers want to have access to traced beef, are willing to pay more for this product and in favor of mandatory beef traceability in Brazil, indicating that a new market niche can be created for the traced beef volume that remains in the domestic market. Therefore, 
traceability can be perceived as a business opportunity for the Brazilian beef production chain, and is considered an important differentiating and value-adding tool.

\section{References}

ANGULO, A.M.; GIL, J.M. Risk perception and consumer willingness to pay for certified beef in Spain. Food Quality and Preference, v.18, p.1106-1117, 2007.

BARCELLOS, J.O.J.; SUÑE, Y.B.P.; SEMMELMANN, C.E.N. et al. A bovinocultura de corte frente a agriculturização no Sul do Brasil. In: CICLO DE ATUALIZAÇÃO EM MEDICINA VETERINÁRIA, 11., 2004, Lages. Anais... Lages: Centro Agroveterinário de Lages, 2004. (CD-ROM).

BERNUÉS, A.; OLAIZOLA, A.; CORCORAN, K. Extrinsic attributes of red meat as indicator of quality in Europe: an application for market segmentation. Food Quality and Preference, v.14, p.256-276, 2003a.

BERNUÉS, A.; OLAIZOLA, A.; CORCORAN, K. Labelling information demanded by European consumers and relationship with purchasing motives, quality and safety of meat. Meat Science, v.65, p.1095-1106, 2003b.

BRISOLA, M.V.; CASTRO, A.M.G. Preferências do consumidor de carne bovina do distrito federal pelo ponto de compra e pelo produto adquirido. Caderno de Pesquisas em Administração, v.12, p.81-99, 2005.

CASWELL, J.A. Quality assurance, information tracking and consumer labeling. Marine Pollution Bulletin, v.53, p.650-656, 2006.

CODEX ALIMENTARIUS. Food import and export inspection and certification systems. WHO, Roma, 2007. 91p.

COLTRO, A. Estratégia de fomento à sustentabilidade: Diferenciais validados pelos consumidores? REA - Revista Eletrônica de Administração, v.124, p.132-184, 2007.

FERREIRA, G.C.; BARCELLOS, M.D.; VIEIRA, L. Rastreabilidade faz a diferença. Agroanalysis, v.27, p.44-45, 2007.
GÓMEZ, M.A.R. Trazabilidad: el reto de la industria general y de la cadena alimentaria em particular. Distribución y Consumo, v.14, p.53-62, 2004.

JONES, E.; POGHOSYAN, A.; GONZALEZ-DiAZ, F. et al. Traceability and assurance protocols in the global food system. International Food and Agribusiness Management Review, v.7, p.118-126, 2004.

MACHADO, R.T.M. Sinais de qualidade e rastreabilidade de alimentos: uma visão sistêmica. Organizações Rurais \& Agroindustriais, v.7, p.227-237, 2005.

MALAFAIA G.C.; BARCELLOS, J.O.J.; AZEVEDO, D.B. Construindo vantagens competitivas para a pecuária de corte do Rio Grande do Sul: o caso da indicação de procedência da "Carne do Pampa Gaúcho”. In: SEMINÁRIOS EM ADMINISTRAÇÃO (SEMEAD), 9., 2006, São Paulo. Anais... São Paulo: Universidade de São Paulo, 2006. (CD-ROM).

NEVES, M.F.; SCARE, R.F. Brascan: how to capture value in the beef chain. In: RUBEN, R.; SLINGERLAND, M.; NIJHOFF, H. (Org.) Agro-Food Chains \& Networks for Development, v.14, p.141-152, 2006.

RIJSWIJK, W.; FREWER, L.J.; MENOZZI, D. et al. Consumer perception of traceability: a cross-national comparison of the associated benefits. Food Quality and Preference, v.19, p.452-464, 2008.

SEPÚLVEDA, W.; MAZA, M.T.; MANTECÓN, A.R. Factors that affect and motivate the purchase of quality-labelled beef in Spain. Meat Science, v.80, p.1282-1289, 2008.

TOOTELIAN, D.H.; SEGALE, J. The importance of place of origin in purchase decisions for agricultural products. Journal of Food Products Marketing, v.10, p.27-43, 2004.

VELHO, J.P.; BARCELLOS, J.O.J.; LENGLER, L. et al. Disposição dos consumidores porto-alegrenses à compra de carne bovina com certificação. Revista Brasileira de Zootecnia, v.38, p.399-404, 2009.

VIEIRA, L.; FERREIRA, G.C.; BARCELlos, M.D. Papel da rastreabilidade. Agroanalysis, v.27, p.26-27, 2007.

VILLALOBOS, P.; PADILLA, C.; PONCE, C. et al. Beef consumer preferences in Chile: importance of quality attribute differentiators on the purchase decicion. Chilean Journal of Agricultural Research, v.70, p.85-94, 2010. 